
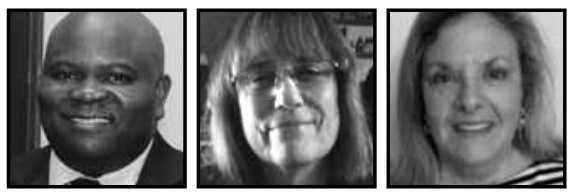

\title{
Shared Stories of Successful Graduates of Juvenile Residential Programs
}

\author{
Barrett Mincey \& Nancy Maldonado, Walden University \\ \& Candace Lacey, Nova Southeastern University
}

\section{ABSTRACT}

This phenomenological study explored stories of successful graduates of residential programs regarding their experiences while in treatment. Participants were purposefully selected. Data were collected through audio-taped interviews and analyzed for themes. Shared stories indicated the impact of counselors, negative and positive aspects of programs, and peer relationships.

\section{Context}

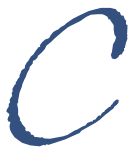

riminologists and lawmakers often ponder the rationale for juvenile delinquency and recidivism. Several risk factors have been linked to define the problem of juvenile crime such as poverty, peer relations, school, family life, and community dynamics. Young people who are negatively influenced by these risk factors have greater chances of becoming involved with the juvenile justice system (Brank, Lane, Turner, Fain, \& Sehgal, 2010; Contraras, Molina, \& del Carmen Cano 2011; Matjasko, Needham, Grunden, \& Feldman Farb, 2010; Stein, Milburn, Zane, \& Rotheram-Borus, 2009). Granello and Hanna (2003) reported that high rates of criminal activity by adolescents have increased the number of adolescents being court-ordered to correctional facilities, adult jails, and juvenile residential treatment programs.

Young people are committed to juvenile residential programs of various levels (e.g., level 4 - low risk, level 6 - moderate risk, level 8 - high risk, and level 10 
- severe risk) (See Appendix A). Their successes or failures within and/or after commitments may depend on how motivated they are to become rehabilitated, the program commitments to providing services that are geared toward youth competency development, and the community involvement after young people are released back into their natural environments. This presents a question that many stakeholders continue to ask: How do key stakeholders address juvenile delinquency in a balanced way? Court systems continue to modify policies in an effort to provide solutions that are beneficial to the community and juveniles.

\section{Theoretical Framework}

Hirschi's Control Theory and the Differential Association Theory (Sutherland $\&$ Cressey, 1970) provide theoretical perspectives on juvenile delinquency and recidivism. Both theories establish rationales for why young people engage in deviant behaviors. Control theory suggests that young people select friends who have similar inclinations to delinquency (Knect, Snijders, Baerveldt, Steglich, \& Raub, 2010). The Differential Association Theory holds that all behavior is learned, delinquent behavior is learned in small groups, and delinquent behavior is learned from collective and specific situational events (Knect et al., 2010; Sutherland \& Cressey, 1970).

\section{Literature Review}

\section{Risk Factors for Delinquency}

Jensen and Vance (2004) offered an analysis of a New Hampshire juvenile correctional system's strength-based perspective in measuring clients' risk and protective factors. They credited the system for assisting youngsters in developing protective factors. It is common that "youths with risk factors who do well also have protective factors in their lives such as support from positive peers, rules, and routines at home, the ability to function as a good student and some perceived competency" (p. 16).

\section{Family.}

There is much evidence for the correlation between family characteristics and youth crime (Estévez \& Emler, 2010; Matjasko et al., 2010; Yu \& Gamble, 2010). For example, good marital relationships and strong family cohesiveness have been more 
commonly found in families of non-delinquents than delinquents (Clemens \& Miller, 2001; Peterson, Buser, \&Westbury, 2010). Stein et al. (2009) note that positive paternal relationships and attachment to fathers is a protective factor. Parent monitoring of activities and parental supervision of peers also has a positive influence (Brank et al., 2008; Yu, 2010).

On the other hand, a family's inability to positively address children's emotional, intellectual, and social needs often leads to crime (Brank et al., 2008; Matjasko et al., 2010; Yu \& Gamble, 2010). Furthermore, certain negative behaviors by parents often lead to negative outcomes. For instance, Brank et al. (2008) discuss the relationship between a lack of parental monitoring and violence. Matjasko et al. (2010) observe that harsh parenting and a lack of family closeness are contributors to crime. Stein et al. (2009) point out that parental drug and alcohol abuse often lead to negative behaviors. In addition, broken homes, family disruptions, and one-parent homes often lead to delinquency (Contreras, Molina, \& del Carmen Cano; 2011; Grunwald, Lockwood, Harris, \& Monnis, 2010; Schroeder, Osgood, \& Oghia, 2010).

\section{School/education.}

Effective schooling for students in the juvenile justice system often leads to more positive outcomes. Mathur and Schoenfeld (2010) note that education for young people in the juvenile justice system will likely be the greatest way to influence behavior. Sander (2010) suggests that skill building and school experiences that are positive are essential, and Mathur and Schoenfeld (2010) stress the importance of teachers and peer tutoring. Brodie (2009) points out the value of schooling that has high standards and expectations. Mathur and Schoenfeld (2010) in their discussion of education for young people in the juvenile justice system, assert that, "To succeed in providing a high-quality education to adjudicated youth with special needs, correctional facilities must change their focus from an emphasis on custodial care to the academic success of students in their schools" (p. 25).

Peers.

All young people need friends, and peer relationships can be positive or negative (Brank et al., 2008). Troubled youth need positive peers; however, this is often not the case. Youths who find themselves involved in antisocial peer relationships are more likely to engage in negative behaviors (Brank et al., 2008; Miller, 2010; Yu \& Gamble, 2010). Harding (2009) points out that there is a large correlation between negative peer relationships and delinquency/drug use and adds that disadvantaged youth are more likely to associate with older peers, and this can be problematic. Grunwald et al. (2010) discuss the problems associated with unsupervised peer groups, 
and Smith and Chonody (2010) contend that negative peer influence often leads to drug abuse.

Matjasko et al. (2010) discuss "peer networks" and how these relate to violence, noting that peers often seek out others who are violent and that "peers are a critical determinant of violent perpetration" (p. 1055). Mouttapa et al. (2010) point out that some young people who are not gang members identify with the gang member mentality and then adopt some gang member behaviors. In addition, peers can often negatively influence the behavior of others while they serve time in the same correctional facility (Bayer, Hjalmarsson, \& Pozen, 2009).

\section{Poverty/socioeconomic status.}

The socioeconomic status (SES) of families is often a predictor of crime activity. Young people who are poverty stricken and living at disadvantage are more likely to engage in criminal behaviors than those who are not living in poverty (Kirk, 2008). Low SES often leads to violence (Matjasko et al., 2010) and frequently to substance abuse (Peterson et al., 2010). In addition, economic disadvantage may contribute to drug dealing, reoffending, and recidivism (Contreras et al., 2011; Grunwald et al., 2010).

\section{Community/neighborhood.}

Deprived or disadvantaged neighborhoods often have juveniles who turn to offending behaviors and recidivism (Estévez \& Emler, 2010; Kirk, 2008; Matjasko et al. 2010). Grunwald et al., (2010) discuss several aspects of deprived neighborhoods, noting that neighborhood processes often lead to juvenile violence, drug dealing, and drug reoffending; they add that residential mobility may be a predictor of juvenile property crime. Little and Steinberg as cited in Grunwald et al. (2010) report that "adolescents who sold the most drugs were more likely to live in contexts characterized by high physical and social disorder..." (p. 1069).

Matjasko et al. (2010) report that violence is highly concentrated in disadvantaged communities, and the young people who live in these deprived communities have to deal not only with their own problems, but also with the problems of others in the neighborhood. Kirk (2008) maintains that the cultural norms of the community contribute to negative behavior, and the norms often lead to a tolerance for lawlessness and criminal behavior.

\section{Program approaches.}

Wertz (2004) advocates a multi-systemic approach to reducing adolescent 
crime, recidivism, and substance abuse. Multi-systemic Therapy (MST) involves the school, family, and community to achieve positive behavioral changes for juvenile offenders. The major objective of MST is to address the familial, school, peer, and community-related sources that positively impact children's behaviors. Knorth, Harder, Zandberg, and Kendrick (2007) discuss the value of programs that apply behaviortherapeutic methods. Likewise, Lowenkamp, Makarios, Latessa, Lemke, and Smith (2010), in their discussion about juvenile facilities in Ohio, note that "cognitive and behavioral modalities" contribute to effectiveness (p. 697). Sung, Chu, Richter, and Shlosberg (2009), in their examination of Teen Challenge USA (TC) emphasize a different approach—faith-based recovery services. However, Sung et al. (2009) call for collaboration between social scientists and the faith-based therapists.

\section{Program focuses.}

Several researchers and writers focus on employment and responsibility for rehabilitated youth. For example, Selm (2001) demonstrates how at-risk young people can be assisted in making positive turnarounds from further delinquency in a discussion of a program designed to rehabilitate young people and strengthen community and family support, encourage gainful employment, and create a sense of responsibility. Similarly, Cohen and Piquero (2010) discuss the YouthBuild (YB) Defender Program that aims for future employment.

Life experiences can provide a perspective about how young offenders can be reached (Bond, 2001). Operation Outreach is a specialized prison facility within the Texas Department of Criminal Justice (TDCJ) designed to provide juvenile offenders with a prison perspective and to help them realize the possible results they could face if they continue their criminal behavior. This program helps young offenders gain perspective, self-awareness, lose bad habits, and learn tools for life (Bond, 2001). As well, promoting effective life skills is the aim of other programs (Cohen \& Piquero, 2010; Sander, 2010).

\section{Staff members.}

Qualified, experienced, and well-trained staff members are an integral part of effective treatment programs (Lowenkamp et al., 2010; Knorth et al., 2007). In fact, Knorth et al. (2007) assert that "the staff of a residential program seems to be more critical in assessing behavioral progress than youth themselves and their parents" ( $p$. 136). Lowenkamp et al. (2010) point out that well-qualified, trained staff members help to reduce recidivism. As well, qualified, credentialed counselors add to the effectiveness of intervention programs (Leone, Roget, \& Norland, 2008; Lowenkamp et al., 2010). 


\section{Research Question}

Finding ways to reduce recidivism continues to be one of the most challenging issues in the area of crime prevention. The review of literature specifies that the major issues surrounding delinquency and recidivism are family, school/education, peers, neighborhood/community, and/or poverty and that researchers need to understand how the aforementioned affect society as a whole. Key stakeholders are encouraged to consider the "lived experiences" of those individuals who have experienced this phenomenon. Therefore, the research question that guided this study was: What are the shared stories of successful graduates of residential programs regarding their experiences while in treatment?

\section{Methods}

\section{Philosophical Paradigm}

Constructivism serves as the philosophical paradigm for the study. Denzin and Lincoln (2005) indicate that the constructivist/interpretivist perspective allows for multiple realities to exist. This epistemological assumption establishes a basis for determining the essence of knowledge, the relationship between the knower and the known, as well as the nature of truth. The knower interprets and constructs a reality that is based upon experiences and interactions within the environment. Through these lived experiences, truth can be explained from an emic perspective (Denzin \& Lincoln, 2005).

\section{Rationale for Selected Approach}

Phenomenology is the approach that was used to unravel the essence of this study (Creswell, 2007; Hatch, 2002; Merriam, 2009). An important characteristic of phenomenology is the belief that human behavior is contextual. Behavior is observed and studied holistically and in context rather than being reduced to parts and manipulated (Creswell, 2007; Merriam, 2009). Within this holistic perspective, "the whole phenomenon under study is understood as a complex system that is more than the sum of its parts; focus is on complex interdependencies not meaningfully reduced to a few discrete variables and linear, cause-effect relationships" (Gay \& Airasian, 2000, p. 205). 


\section{Data Generation}

\section{Participants.}

Data were collected from nine young adult participants who had satisfied their court-ordered sanctions in different residential facilities and who had successfully completed their aftercare supervisions (See Appendix B). Participants had been adjudicated as delinquents by the courts and committed to the Florida Department of Juvenile Justice. These young adults had previously served in a level four (low-risk), level six (moderate-risk), level eight (high-risk), or level ten (maximum-risk) treatment program and were currently receiving post-secondary instruction in a college/vocational school or were gainfully employed.

\section{Instrument.}

The interview protocol emerged from the review of the literature (See Appendix C). The interview question that is examined in this paper is Question 1: What stories can you share regarding your experiences in a residential treatment program?

\section{Data Collection and Processing}

The interviews were tape-recorded by a digital recording device, and the researchers took handwritten notes in order to highlight important points that were expressed by the participants. A professional transcriptionist transcribed the interviews. The verbatim transcripts were reviewed and checked for accuracy.

In order to protect the rights of the participants, all information they provided was held in confidence to the extent permitted by law. Any published results of the research will retain the confidentiality of the participants; pseudonyms were used in place of actual names. Confidentiality was maintained to avoid privacy invasion and potential psychological harm to the participants, and participants were informed that their participation was voluntary (Berg, 2004; Gay \& Airasian, 2000).

\section{Data Analysis}

Once the transcription process was completed, the researchers coded the transcripts in order to find themes, patterns, or clusters of meanings that the participants revealed in their responses. Each response to the interview questions was reviewed on a line-by-line basis. 
The researchers used NVivo software to organize text and/or audio and data files. Further interpretation allowed the researchers to develop a textual description, a structural description, and an overall description of the experience or essence (Creswell, 2007).

\section{Steps to Ensure Trustworthiness}

Guba's model for identifying rigor in qualitative research includes truth value, applicability, consistency, and neutrality (as cited in Krefting, 1991). Trustworthiness is often used in qualitative studies rather than internal and external validity, reliability, and objectivity. In order to ensure credibility, the researchers used peer examination, reframing of questions, triangulation, and reflexivity. In order to enhance dependability, the researchers used triangulation, a code-recode procedure, and qualitative analytic software.

Confirmability is similar to objectivity in quantitative studies (Milinki, 1999). The rationale behind confirmability is that it helps to ensure the interpretations of the inquiry have logical and clear linking associations. Reflexive analysis was used to make certain that the researchers were aware of any personal influences (Berg, 2004).

\section{Findings}

The nine participants were asked to share stories regarding their experiences in residential treatment programs. Some of the participants shared similar experiences, and other participants reported diverse encounters. The impact of counselors, negative and positive aspects of their programs, and peer relationships were all issues that emerged from the participants' responses. "Sincere" described his experiences as different:

The environment was different. You have to learn to live around people that you have never lived around before. The experience was different from what I was used to back home in Miami. The staff there in Central Florida was mostly white. They wanted you to behave like them. It was a lot of work from $7 \mathrm{am}$ to $8 \mathrm{pm}$. Sometimes we did stuff that had no meaning (with emphasis). For instance, the guards instructed us to dig a hole. After the hole was dug, we were told to cover it up. I believe that we were told to do certain things just to waste time. It was a new experience, an eye opener. I saw people who 
would come there who would be playful, social, or just be loners such as myself.

"Happy" shared variant perspectives of his environment in a level eight program:

The environment was crazy because sometimes when you think you are doing the right thing, the program staff make you seem like you are doing the wrong thing; they sent us a lot of mixed messages. When I tried to put forth my best effort in fulfilling my goals in the program, somebody or something would just hold me back. But then I began to remember and apply what I learned from my level six program. I started writing down ways to handle complex situations that I faced daily.

"Happy" observed situations and positioned himself so that he would not get caught up in the dramatic episodes of the program. He acquired these skills from his previous level six program. Throughout the program, "Happy" reported gaining confidence and greater determination.

\section{Impact of Counselors}

Counselors had a major impact on how the participants perceived their programs. In fact, three of the participants reported that successful programs have counselors who are competent, compassionate, and who use tough love to "break you down and build you up." The counselors were looked upon as rationales for why some youth succeed and why others fail; the compassionate counselors assisted greatly in the success of young people. "John" distinguished counselors as either bad or good:

Good counselors talked to me and used a tough love approach by telling me that I scarred my life by involving myself in negative behaviors. They did not judge me but tried to provide me with a better alternative to crime. Bad counselors were negative towards me and called me a "bad ass git" (meaning an ungovernable young thug). They treated me and others like "shit" and often reminded me of my faults and criminal past, which in some way caused me to lose faith in all counselors.

"Sincere" shared personal accounts on counseling services:

Some counselors provided insight and helped me conquer some of 
my problems. Other counselors were just vague and went through the motions. The older counselors were more serious and more practical than the younger ones. The younger staff had difficulty listening to us. But the older counselors (some who were Vietnam Veterans) were able to provide us with some of their difficult experiences that gave us more insight about the world we had never heard about.

"Sam" stated that the counseling services within his program were beneficial:

The counselors had an interest in us: about what we thought and felt; they interacted with us in ways that made us comfortable. They assisted us with our problems. For example, when we talked about our crimes, they would provide us with good solutions; they helped us understand how to think before we act. They would allow us to be part of the solution by saying things like: What could you have done differently to get a better solution?

The effective counselors appeared to be the reformers: the ones who assisted greatly in juvenile rehabilitation. The ineffective counselors (that John described as bad) had a tendency to spoil the whole bunch: they were perceived negatively by young people and may have created a trust issue between the counselors and youth.

Trust was an important issue for counselors and those receiving counseling services. Two of the participants highlighted trust as major determinants on whether they opened up to people. "John" noted that he could trust some counselors because they maintained respect for him and kept confidential matters private. Conversely, "some counselors were not trustworthy, and that alone could damage you because you place your trust in them and they talk about you." "Tom" expressed that sensitivity is a prerequisite for gaining trust:

Within my program, I don't feel that the counselors were as sensitive as they should have been. I feel that they should have put a little more effort in trying to understand the person and his issues first. And when things get difficult, don't just give up hope because it might take a while to gain the trust of somebody; but once you have gained their trust, that is when you can really help them.

"Happy" shared that he built a level of trust with his counselor that proved beneficial to his successful transition: 
I was initially having some rough times in my level six program, so I sat down with my counselor and asked for help. He helped me put together a "todo" list that included good objectives and bad objectives. My counselor told me that if I followed the good objectives, I would make my stay in the program a lot less stressful and I would achieve success. Some of the things that I realized needed to change were: 1) My attitude: instead of approaching people in a rough manner, I generally learned how to respect others by saying things like "Good evening, and How are you doing?" 2) Focus more in school. I practiced and strengthened my academics by asking for more challenging work. 3) Learning to bond with peers better-basically, I had to bond with them as I would bond with a child or my brothers and sisters. Once I did these things, I gave the impression to the program staff that I was ready to go home.

Counselors have myriad roles in the process of juvenile rehabilitation. Their effectiveness was derived from four areas: competency, compassion, sensitivity, and trust.

\section{Negative Aspects of Programs}

Several participants shared negative experiences about their programs. One participant described negative situations he encountered in the system that proved detrimental to his ability to fulfill his program objectives. Three of the participants expressed complete dissatisfaction with the educational services. There was no rigor in the educational component. The teachers were described as being ineffective. "John" and "Happy" explained further that the teachers did not teach; "They just gave you work and stated that you will need this for credit towards graduation." The school component was just a way to "kill" time. "Bob" indicated that he used to crawl behind the teacher's desk and go to sleep; he also reported that he made straight A's for six months. "John" and "Happy" reported receiving satisfactory educational services in their outpatient programs.

General program components included negative aspects as well. "Sam" commented about the directors of his program. He expressed that the directors abused their power. He specifically disagreed with the way the directors assumed a superiority-inferiority complex when dealing with the clients:

They do things that make you want to catch another charge: like talking to you any kind of way. They know that we are powerless because if we say something back, they can violate us and then we're back in front of the judge with a possibility of being sent to a higher level program; they test our limits. 
"Mike" stated on several occasions that he witnessed staff inappropriately use improper restraining procedures toward clients in a level 8 (high-risk) program. "Mike" had been in a variety of residential programs and could demonstrate proper restraint procedures:

I know how to restrain somebody correctly because I have been locked up in the system for so long. I don't like to see other people get hurt. I put myself in their situation so that they would stop messing with the other people and focus on me. I put my hand on staff and I got kicked out of that program.

"Mike" observed this situation from a critical theorist's perspective; he discovered a particular injustice towards clients in the system and took actions in his own hands. His efforts were detrimental to his ability to attain success and further delayed any attempts at rehabilitation.

"Bob" shared that he received a positive termination from his program although he felt that it was not earned. He believed that the program administrators wanted him out. "Bob's" negative perspective of his program stemmed from the fact that the program was too heavy on rewarding clients for completing menial tasks. For instance, "If you swept the floor two days a week, you would qualify for an 8- to 12-hour home pass."

\section{Positive Aspects of Programs}

Five of the participants provided positive insights regarding their programs. The programs' environments, educational services, and program events were cited as positive aspects. Although other participants experienced negative perceptions of the educational components of their programs, three of the participants applauded the efforts of their teachers. Few of the teachers used non-traditional methods in commanding the interests of their students. "Sincere" indicated that he was given an opportunity to learn from teachers who were very practical in their teaching methods. In particular, the math teachers often interpreted math concepts with items from the students' natural environments (i.e., the streets). "Jim" shared that the teachers in his program were knowledgeable and assisted him with a smile. "The teachers helped transform my non-belief in education to making me believe in school and love it." Jim reported further that the program linked the counseling services with the educational components, resulting in a cohesive team management philosophy.

"Tom" was satisfied with his educational services: 
The educational services were made readily available to me. Most of the teachers were helpful; the classes were small, and more individual help was given when needed. There were always decent supplies. I received my general equivalency diploma (GED) while I was there.

"Sam" described the educational component within his program as good. He shared similar perspectives like both of the previous participants. He credited the teachers for their willingness to assist all students at their individual levels and provide extended assistance when warranted:

You understand them well. They were not the kind of teachers that became frustrated quickly and move on. I feel that the teachers in my program were better than the teachers I had in my regular school because they take their time with you to make you understand.

The same positive regards were shared about their program's environment.

"Sincere" learned how to adapt to what he called a "strange environment," being that he was from an urban environment and was placed into a rural environment. "Tom" expressed that being in his environment was a learning experience. He valued the opportunities to see different races of people from different backgrounds (i.e., people he was not accustomed to being around). This experience "gave me a broader perspective on the way things really are, and I got a chance to get to know a few good people." "Sincere" articulated further that in a level 10 (maximum-risk) program, "You become less bold and prideful because they will break your pride down real fast. Fast; the hard labor will do it. I did not talk back to the officers; I decided to comply with the regulations so that I could go home when my time was completed."

\section{Peer Relationships}

Juvenile offenders in residential programs maintain daily interactions with each other. Four of the participants shared accounts of conflicting situations they either experienced or witnessed firsthand. "Tom" reflected on his past as one reason why he encountered negative associations with peers:

It was very hard for me because growing up, I really did not follow the crowd and I just did not get along with other kids. People looked at me differently and treated me differently. Therefore, there was a lot of conflict with peers when I was in closed environments. I got into fights; people tried to steal from me, that led to more fights. 
"Mike" shared a similar occurrence:

Basically, I had an anger problem, and when I went to my first level six program for mental health reasons, a lot of people used to "talk trash" and start trouble with me. Since I have an anger problem, I would just swing on (i.e., hit) them. I have an issue about my neck, and if they would grab me, then I would swing on them again. I don't bother anyone unless they start with me.

"Jim" explained that his difficult peer relations almost caused him to be transported back to the detention center:

I was accused of snitching on someone, and my peers began to threaten me, spit in my face, and did a lot of ridiculous things to get me to snap. It wasn't a fun experience. They made my time in the program very difficult. I prayed for those home passes so that I could get relieved from what appeared to me as torture.

"Sincere" witnessed fights on a daily basis. He described the fights as either territorial or racial:

Each county had [cliques] of people who represented where they were from, and the larger population of people from a particular county picked fights with the other people from counties who did not have a large [clique]. The population in the program consisted of mostly whites and blacks; the Hispanic population was the minority.

These same offenders also reestablished relationships with peers in their natural environments when they were released from these programs. Four of the participants provided suggestions for young people (who are currently in juvenile residential programs) when they return to their home environments. "John" advised returning youth to focus on how they enhance themselves and to relinquish negative peer associations. "Mike" expressed that "it is good to help others, but you must first help yourself first: that goes along with loving yourself before you can love someone else." He suggested that it is better not to have any friends for a while and use discernment in their associations.

"Jeff" personalized his statement by explaining that consuming drugs and being disobedient towards his parents resulted in him becoming a product of the juvenile justice system. He concluded by saying that partaking of mind-altering 
substances (e.g., drugs and alcohol) may prevent young people from using good judgment and decision-making, subsequently preventing them from attaining successful life outcomes. "Sincere" witnessed strong-minded individuals being consumed by drugs:

Once they took that first puff of marijuana, they were led to other negative things. Drugs are killing the younger generation because these young people are engaging in more serious drug usage. Smoking and negative peers could lead them back into the system.

"Sincere" advised young people to rid themselves of negative friends and to conceal their trust. Trust changes dramatically when they return to mainstream society. He asserted, "Many people who succeed know how to use discrimination when it comes to trust."

\section{Implications and Conclusions}

The impact of counselors, negative and positive aspects of programs, and peer relationships were all issues that emerged from the participants' responses. Counselors had a major impact on how the participants perceived their programs. Participants reported that successful programs have counselors who are competent, compassionate, and who use tough love to "break you down and build you up." The counselors appeared to be the reasons why some youth succeed and why others fail. Participants described the good counselors as ones who talked to them, used a tough love approach, provided insight, helped to conquer problems, were compassionate, showed an interest in them, respected them, and promoted trust. These findings regarding the impact of good counselors is consistent with existing literature (Leone et al., 2008; Lowenkamp et al., 2010; Knorth et al., 2007).

Some participants shared negative experiences about their programs. Several participants expressed complete dissatisfaction with the educational services, one indicated there was no rigor in the educational component, and teachers were described as being ineffective. This finding corresponds to the findings of Mathur and Schoenfeld (2010). Certain program components were also perceived negatively. For instance, participants reported some directors abused their power, some displayed a superiority-inferiority complex when dealing with the clients, some just wanted to get rid of clients, and some used improper restraining procedures toward clients. 
Leone et al. (2008), Lowenkamp et al. (2010), and Knorth et al. (2007) all reinforce the need for well-qualified and well-trained facility staff members.

On the other hand, several participants provided positive insights regarding their programs. The programs' environments, educational services, and program events were cited as positive aspects. Participants applauded the efforts of their teachers and indicated that teachers were knowledgeable. Several participants were satisfied with the educational components of the program. One saw his environment as a learning experience, and another indicated that youth were rewarded for meeting requirements. Similarly, Brodie (2009), Mathur and Schoenfeld (2010), and Sander (2010) point out the need for effective schooling in juvenile justice systems.

Several participants shared accounts of conflicting situations they either experienced or witnessed firsthand regarding peer relationships. They discussed fighting, anger issues, and difficult peer relations. Participants also provided suggestions for young people (who are currently in juvenile residential programs) when they return to their home environments-relinquish negative peer associations, learn to help oneself, avoid drug use. These findings correspond to the findings of existing literature including articles by Brank et al. (2008), Harding (2009), Miller (2010), Matjasko et al. (2010), and Yu and Gamble (2010).

Participants provided a phenomenological view of their experiences in residential treatment programs. Counselors, peer relationships, and program components often determined their successful completions. These stories are important for other juveniles at-risk for delinquency, directors of treatment programs, teachers, and correctional leaders and can be viewed as examples for why some youth succeed and others fail while in treatment. This study explored a social reality that continues to plague the world today. When society establishes a critical look at the juvenile justice system and qualitatively assesses and determines key factors for success, perhaps a consensus for endorsing methods for reducing juvenile delinquency and recidivism can be reached. 


\section{Appendix A}

\section{Program Descriptors}

Once juveniles become adjudicated delinquent, they are mandated by the courts to fulfill judicial sanctions. These sanctions range from adhering to community control (i.e., probation) to commitment status-both sanctions requiring youths be supervised by the state's juvenile justice system. The following descriptions represent the risk levels associated with being on commitment status with the Florida Department of Juvenile Justice (Adapted from the FDJJ website):

1) Level 4 (Low Risk) - Current offenses range from first to second degree misdemeanors or third degree felonies. Offenders serving at this stage typically have failed to complete their diversionary programs and usually have poor family structures.

2) Level 6 (Moderate Risk) - Juveniles who are sanctioned at this stage have been found guilty of committing repeated law infractions. These infractions are typically considered to be serious property crimes.

3) Level 8 (High Risk) - Juveniles at this stage are considered a high risk to the public. They require close supervision in a structured setting that provides 24 -hour secure, custody, care, and supervision.

4) Level 10 (Severe Risk) - This level is considered to be similar to adult prisons. Juveniles are in single cells; these offenders have committed serious violent offenses and other serious felonies. Juvenile offenders who are sanctioned by the courts to this level are given one final chance at rehabilitation before being sent to adult prisons. 


\section{Appendix B}

\section{Participant Demographic and Delinquent History}

\begin{tabular}{|c|c|c|c|c|c|c|}
\hline Age & Race & $\begin{array}{l}\text { First } \\
\text { Arrest }\end{array}$ & $\begin{array}{l}\text { Subsequent } \\
\text { Arrests }\end{array}$ & $\begin{array}{l}\text { Types of } \\
\text { Arrests }\end{array}$ & $\begin{array}{l}\text { Commitment } \\
\text { Levels }\end{array}$ & Siblings \\
\hline $\begin{array}{l}\text { John } \\
\text { (22) }\end{array}$ & Black & $\begin{array}{l}3^{\text {rd }} \text { Degree } \\
\text { Felony }\end{array}$ & $\begin{array}{l}3^{\text {rd }} \text { Degree } \\
\text { Felonies }\end{array}$ & $\begin{array}{l}\text { Drug Posses- } \\
\text { sion } \\
\text { Assault/ } \\
\text { Battery }\end{array}$ & $\begin{array}{l}\text { Level } 4 \\
\text { Level } 6\end{array}$ & $\begin{array}{l}\text { One brother } \\
\text { and three } \\
\text { sisters }\end{array}$ \\
\hline $\begin{array}{l}\text { Bob } \\
(22)\end{array}$ & White & $\begin{array}{l}1^{\text {st }} \text { Degree } \\
\text { Misdemeanor }\end{array}$ & $\begin{array}{l}3^{\text {rd }} \text { Degree } \\
2^{\text {nd }} \text { Degree } \\
\text { Felonies }\end{array}$ & $\begin{array}{l}\text { Vandalism } \\
\text { Burglary } \\
\text { Robbery }\end{array}$ & Level 6 & $\begin{array}{l}\text { One step- } \\
\text { brother and } \\
\text { one stepsiste }\end{array}$ \\
\hline $\begin{array}{l}\text { Tom } \\
\text { (19) }\end{array}$ & White & $\begin{array}{l}1^{\text {st }} \text { Degree } \\
\text { Misdemeanor }\end{array}$ & $\begin{array}{l}\text { Misdemean- } \\
\text { ors } \\
3^{\text {rd }} \text { Degree } \\
2^{\text {nd }} \text { Degree } \\
\text { Felonies }\end{array}$ & $\begin{array}{l}\text { Petty Theft } \\
\text { Vandalism } \\
\text { Drug Usage } \\
\text { Robbery } \\
\text { Burglary }\end{array}$ & Level 6 & $\begin{array}{l}\text { One younger } \\
\text { brother; one } \\
\text { stepbrother } \\
\text { and one step } \\
\text { sister (both } \\
\text { older) }\end{array}$ \\
\hline $\begin{array}{l}\text { Jeff } \\
(22)\end{array}$ & White & $\begin{array}{l}1^{\text {st }} \text { Degree } \\
\text { Misdemeanor }\end{array}$ & $\begin{array}{l}\text { Misdemean- } \\
\text { ors } \\
\text { Felonies ( } 3^{\text {rd }} \\
\text { Degree) }\end{array}$ & $\begin{array}{l}\text { Marijuana } \\
\text { Usage } \\
\text { Underage } \\
\text { Drinking } \\
\text { Burglaries }\end{array}$ & Level 6 & $\begin{array}{l}\text { One younger } \\
\text { brother }\end{array}$ \\
\hline $\begin{array}{l}\text { Mike } \\
(21)\end{array}$ & Black & $\begin{array}{l}1^{\text {st }} \text { Degree } \\
\text { Misdemeanor }\end{array}$ & All Felonies & $\begin{array}{l}\text { Aggravated } \\
\text { Battery } \\
\text { Assault on an } \\
\text { Officer } \\
\text { Escape Charge }\end{array}$ & $\begin{array}{l}\text { Level } 6 \\
\text { Level } 8\end{array}$ & $\begin{array}{l}\text { Two younger } \\
\text { sisters and } \\
\text { one older } \\
\text { brother }\end{array}$ \\
\hline $\begin{array}{l}\text { Sincere } \\
(21)\end{array}$ & Hispanic & $\begin{array}{l}1^{\text {st }} \text { Degree } \\
\text { Misdemeanor }\end{array}$ & Felony & $\begin{array}{l}\text { Petty Theft } \\
\text { Armed } \\
\text { Robbery }\end{array}$ & Level 10 & $\begin{array}{l}\text { One older } \\
\text { sister }\end{array}$ \\
\hline $\begin{array}{l}\text { Sam } \\
(18)\end{array}$ & Black & $\begin{array}{l}1^{\text {st }} \text { Degree } \\
\text { Misdemeanor }\end{array}$ & Two Felonies & $\begin{array}{l}\text { Criminal } \\
\text { Mischief } \\
\text { Burglary } \\
\text { Grand Theft } \\
\text { Auto }\end{array}$ & Level 6 & $\begin{array}{l}\text { Four sisters } \\
\text { and } \\
\text { two brothers }\end{array}$ \\
\hline $\begin{array}{l}\text { Happy } \\
\text { (18) }\end{array}$ & Black & $\begin{array}{l}1^{\text {st }} \text { Degree } \\
\text { Misdemeanor }\end{array}$ & $\begin{array}{l}\text { Misdemeanor } \\
\text { Three Felonies }\end{array}$ & $\begin{array}{l}\text { Petty Theft } \\
\text { Marijuana } \\
\text { Possession } \\
\text { Burglary } \\
\text { Larceny }\end{array}$ & $\begin{array}{l}\text { Level } 6 \\
\text { Level } 8\end{array}$ & $\begin{array}{l}\text { One brother } \\
\text { and } \\
\text { three sisters }\end{array}$ \\
\hline $\begin{array}{l}\mathrm{Jim} \\
(20)\end{array}$ & White & $\begin{array}{l}3^{\text {rd }} \text { Degree } \\
\text { Felony }\end{array}$ & Felonies & $\begin{array}{l}\text { Burglary } \\
\text { Robbery } \\
\text { Drug } \\
\text { Possession }\end{array}$ & Level 6 & One sister \\
\hline
\end{tabular}




\section{Appendix C}

\section{Interview Protocol}

1. What stories can you share regarding your experiences in a residential treatment program?

2. How were you able to overcome the repeating pattern of further delinquency?

3. How are you able to remain focused and goal-oriented given your past juvenile delinquent record?

4. Given your experiences in a residential treatment program, what experiences can you share that could assist young offenders in making a positive transition from a residential program to mainstream society?

5. Given your experiences in the juvenile justice system, what changes would you recommend to correctional leadership?

6. From your recent residential experience, what can you share regarding the educational component (e.g., school and counseling services) within your program?

7. Reflecting on your past experiences in and out of residential treatment programs, how can you account for why some succeed (including yourself) and why others fail?

\section{References}

Bayer, P., Hjalmarsson, R., \& Pozen, D. (2009). Building criminal capital behind bars: Peer effects in juvenile corrections. The Quarterly Journal of Economics 124(1), 105-147.

Berg, B. L. (2004). Qualitative research methods for the social sciences (5th ed.). Boston: Allyn and Bacon.

Bond, E. L. (2001). Operation outreach: Reaching out to youths through real-life experience. Corrections Today, 63(1), 46-49.
Brank, E., Lane, J., Turner, S., Fain, T., \& Sehgal, A. (2008). An experimental juvenile probation program: Effects on parent and peer relationships. Crime \& Delinquency, 54(2), 193-224.

Brodie, J. M. (2009, July). Advocate: Juvenile justice programs need revamping. Education Daily, 42(122), 2-4.

Clemens, B., \& Miller, S. J. (2001). Juvenile justice in America (3rd ed). Upper Saddle River, NJ: Prentice Hall. 
Cohen, M. A., \& Piquero, A. R. (2010) An outcome evaluation of the YouthBuild USA offender project. Youth Violence and Juvenile Justice, 8(4) 373-385.

Contreras, L., Molina, V., \& del Carmen Cano, M. (2011). In search of psychosocial variables linked to the recidivism in young offenders. European Journal of Psychology Applied to Legal Context, 3(1), 77-88.

Creswell, J. W. (2007). Qualitative inquiry and research design: Choosing among five traditions. (2nd ed.). Thousand Oaks, CA: Sage.

Denzin, N. K., \& Lincoln, Y. S. (2005). The landscape of qualitative research: Theories and issues. (2nd ed.). Thousand Oaks, CA: Sage.

Estévez, E., \& Emler, N. R. (2010). A structural modeling approach to predict adolescent offending behaviour from family, school and community factors. European Journal on Criminal Policy \& Research, 16(4), 207-220.

Gay, L. R., \& Airasian, P. (2000). Educational research: Competencies for analysis and application (6th ed.). Upper Saddle River, NJ: Merrill Prentice Hall.

Granello, P. F., \& Hanna, F. J. (2003). Incarcerated and court-involved adolescents: Counseling an at-risk population. Journal of Counseling and Development, 81(1), 11-18.

Grunwald, H. E., Lockwood, B., Harris, P. W., \& Monnis, J. (2010). Influences of neighborhood context, individual history and parenting behavior on recidivism among juvenile offenders. Journal of Youth Adolescence, 39(9), 1067-1079.

Harding, D. J. (2009). Violence, older peers, and the socialization of adolescent boys in disadvantaged neighborhoods. American Sociological Review, 74(3), 445-464.

Hatch, J. A. (2002). Doing qualitative research in educational settings. Albany: State University of New York.

Jensen, E., \& Vance, E. (2004). New Hampshire institutes a strength-based perspective. Corrections Today, 66(3), 16-17.

Kirk, D. S. (2008). The neighborhood context of racial and ethnic disparities in arrest. Demography, 45(1), 55-77.
Knect, A., Snijders, T. A. B., Baerveldt, C, Steglich, C. E. G., \& Raub, W. (2010). Friendship and delinquency: Selection and influence process in early adolescence. Development, 19(3), 494-514.

Knorth, E. J., Harder, A. T., Zandberg, T., \& Kendrick, A. J. (2007). Under one roof: A review and selective meta-analysis on the outcomes of residential child and youth care. Child and Youth Services Review, 30(2), 123-140.

Krefting, L. (1991). Rigor in qualitative research: The assessment of trustworthiness. American Journal of Occupational Therapy, 45(3), 214-222.

Leone, M. C., Roget, N. A., \& Norland, J. H. (2008). Clinical supervision of courtreferred juvenile offenders: Are juvenile referrals the least among equals. Children and Youth Services Review, 31(4), 451-456.

Lowenkamp, C. T., Makarios, M. D., Latessa, E. J. Lemke, R., \& Smith, P. (2010). Community corrections facilities for juvenile offenders in Ohio: An examination of treatment integrity and recidivism. Criminal Justice and Behavior, 37(6), 695-708.

Mathur, S. R., \& Schoenfeld, N. (2010) Effective instructional practices in juvenile justice facilities. Behavioral Disorders, 36(1), 20-27.

Matjasko, J. L., Needham, B. L., Grunden, L. N., \& Feldman Farb, A. (2010). Violent victimization and perpetration during adolescence: Developmental stage dependent ecological models. Journal of Youth and Adolescence, 30(9), 1053-1066.

Merriam, S. B. (2009). Qualitative research: a guide to design and implementation. San Francisco: Jossey-Bass.

Milinki, A. K. (1999). Cases in qualitative research: Research reports for discussion and evaluation. Los Angeles: Pyrczak.

Miller, H. V. (2010). If your friends jumped off a bridge, would you do it too?: Delinquent peers and susceptibility to peer influence. Justice Quarterly, 27(4), 473-491.

Mouttapa, M., Watson, D. W., McCuller, W. J., Sussman, S., Weiss, J. W., Reiber, D. L., et al. (2010). I'm mad and I'm bad: Links between self-identification as a gangster, 
symptoms of anger, and alcohol use among minority juvenile offenders. Youth Violence and Juvenile Justice, 8(1), 71-82.

Peterson, C. H., Buser, T. J., \& Westbury, N. G. (2010). Effects of familial attachment, social support, involvement, and selfesteem on youth substance use and sexual risk taking. The Family Journal, 18(4), 369-376.

Sander, J. B. (2010, December). School psychology, juvenile justice, and the school to prison pipeline. Communique, 39(4), 4-6.

Schroeder, R. D., Osgood, A. K., \& Oghia, M. J. (2010). Family transitions and juvenile delinquency. Sociological Inquiry, 80(4), 579-604.

Selm, L. A. V. (2001, July). Reintegration center for South Africa's juvenile offenders (Corrective action holdings) (Company profile). Corrections Today, 63(4), 28-31.

Smith, S., \& Chonody, J. M. (2010). The Teen Court Peer Influence Scale (TCPIS: Determining an effective way to measure and model positive peer influence. Youth, Violence and Juvenile Justice, 8(2), 148-159.
Stein, J. A., Milburn, N. G., Zane, J. I., \& RotheramBorus, M-J. (2009). Paternal and maternal influences on problem behaviors among homeless and runaway youth. American Journal of Orthopsychiatry, 79(1), 39-50.

Sung, H-E., Chu, D., Richter, L., \& Shlosberg, A. (2009) Treatment philosophy and service delivery in a network of faith-based substance abuse treatment. Families in Society, 90(4), 390-398.

Sutherland, E. H., \& Cressey, D. R. (1970). Criminology (8th ed.). Philadelphia: Lippincott.

Wertz, M. S. (2004, March/April). Violence prevention program works with youth where they live. Children's Voice, 13(2), 24.

Yu, J. J. (2010). Reciprocal influences between parental knowledge and adolescent selfcontrol: A cross-sequential nationwide study of Korean youth. Journal of Family Psychology, 24(4), 458-467.

Yu, J. J., \& Gamble, W. C. (2010). Direct and moderating effects of social affordances on school involvement and delinquency among young adolescents. Journal of Research on Adolescence, 20(4), 811-824.

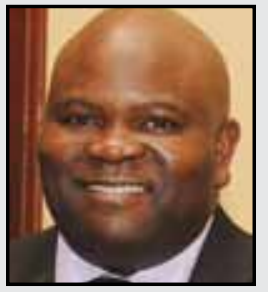

Barrett Mincey received his Bachelor of Business degree in International Finance and Marketing from the University of Miami and a Master's degree in Finance from Salisbury University. After working in the fields of business and education for a number of years, Barrett received a PhD in Educational Leadership from Barry University. Barrett's research interests are juvenile justice, servant leadership, organizational change, and community improvement and redevelopment. In 1991, Barrett instituted an educational program entitled: Big Chief Productions (BCP). The mission of BCP is to assist underprivileged/high risk youth in surmounting the unique challenges that often undermine the pursuit of their career goals. 


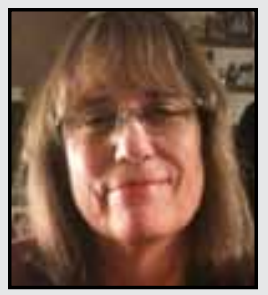

Nancy Maldonado is an adjunct faculty member at Walden University where she teaches leadership and research. She holds a PhD in Educational Leadership and an MA in English from Barry University. Nancy taught English at the high school level for 13 years and has 10 years of experience working with doctoral students as online and face-to-face instructor as well as PhD and EdD dissertation chair and committee member. She has published more than 30 peer-reviewed articles and has more than 50 peer-reviewed presentations at research conferences such as the American Educational Research Association (AERA) annual conference and the Florida Educational Research Association (FERA) annual conference.

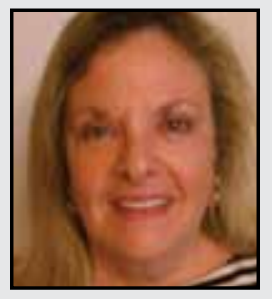

Candace Lacey is a Program Professor at the Fischler School of Education at Nova Southeastern University where she teaches leadership and research. She has earned a PhD in leadership, an MBA, and a BFA. She is a former fellow at the National Center for Education Statistics and is past president of the Consortium of State and Regional Educational Associations, an affiliate organization of the American Educational Research Association. Her research interests and publications include peace education, moral and ethical leadership, and technology use in education and research. Her recent publications include Partners in Peace, Moral Leadership Defined, and Online Teaching: A Framework for Success. 